\title{
DIVERSITY OF MACROPHYTES IN SOME LENTIC WATERBODIES OF GONDIA, DISTT. GONDIA.
}

\author{
Wasudha J. Meshram \\ Department of Zoology, Jagat Arts, Commerce and I.H.P. Science College, \\ Goregaon -441801, Distt. Gondia, (Maharashtra). \\ Email id: wasudhagajbhiye@gmail.com
}

Communicated : 20.12.19

Revision : 08.01 .2020

Accepted : 26.01.2020

Published: 30.01 .2020

\begin{abstract}
:
In a natural ecosystem macrophytes have been used to remove both toxic and non-toxic elements in the sediments and water. The present study was carried out to study the diversity of aquatic communities with reference to macrophytes of Chirebandi pond (C.P.), Devtaki pond(D.P.) and Railway station pond(R.P.) during the period from June 2005 to May 2007. These ponds are one of the large sources of flora and fauna including molluscans and other animals, which are very much economically important. During the present study total24 species belonging to four groups such as free floating, submerged, marginal and emergent macrophytes from the littoral and sublittoral zones of three ponds.
\end{abstract}

Key words: - Diversity,Macrophytes, Fresh water bodies.

\section{INTRODUCTION:}

Aquatic macrophytes are the visible forms of aquatic vegetation which serves as a good source of food to mankind and animals that is a best result for aquatic wild life conservation practices. The trophic nature is mainly influenced by the variety of communities and indicator species occurring at the source. Moreover, metabolic activities of macrophytic communities accelerate the metabolic and the physico-chemical conditions of aquatic ecosystem.

The macrophytes stimulate the growth of phytoplankton and help in the recycling of organic matter. The macrophytes also provide suitable breeding and sheltering place for macroinvertebrates and fishes. (Meshram, 2003).

Macrophytes in fresh water play major ecological role and help in regulation and stabilization of trophic state and mineral cycling in an aquatic ecosystem. They serve as the bioindicators for the possible degree of damage in aquatic ecosystem. A sufficient literature has been generated on macrophytes of various water bodies, Ghavzan et al.,(2006), Kumar and Pandit(2005) and Devi(2007). The present investigations was undertaken to study the diversity of Macrophytesfrom three water bodies namely Chirebandi pond(C.P),Devtaki pond(D.P) and Railway station pond(R.P.).

\section{MATERIAL \& METHODS}

Macrophytes were collected at monthly intervals during the period of investigation from shallow littoral zone by hand picking method. Specimens were washed thoroughly with water, excess water soaked with filter paper, Specimens were kept in polythene bags and brought to the laboratory in ice box and identified up to species with the help of standard literature from Edmondson, (1959); APHA, (1975): Pennack, (1978); Tonapi, (1980); Fasset, (2000). 


\section{RESULT AND DISCUSSION}

The study of macrophytic diversity of three lakes presented in table 1.In the present study, 24 species from four groups were recorded from the three ponds during 2005-2007.

Free floating species were abundant in Devtaki pond and Railway Station pond than Chirebandi pond. Submerged and Emergent species were dominant in Chirebandi pond as compared to Devtaki pond and Railway Station pond. Marginal species showed their dominance in Devtaki pond and Railway Station pond but less in Chirebandi pond.

In the present study, among the free floating weeds, Eichhornia crassipes, Pistia spp., Lemna minor were recorded from Devtaki pond and but dense in Railway Station pond are considered as pollution tolerant species. Azolla spp. was recorded only from Chirebandi pond and considered as pollution free species, Narayana and Somashekhar (2002).

Among the submerged weeds, Vallisneria spp., Ceratophyllum spp. Najas minor, Hydrilla spp., Utricularia spp., Chara vulgaris were recorded from Chirebandi pond and not in Devtaki pond and Railway Station pond. Vallisneria spp. And Ceratophyllum spp., Chara vulgaris are the species that preferably grow at unpolluted pond. Among the marginal weeds, Cyperus spp., Marsilea quadrifolia, Marsilea minuta, Typha spp. and Ipomoea aquatica in Devtaki and Railway station pond. However, Chirebandi pond showed more dominanace of Jassiaea spp., Ludwigia spp. And Lythrum spp. while very scarce distribution of Typha and Ipomoea aquatica.The emergent weeds like Nymphoides spp., Nelumbo spp., andNymphaea spp. were recorded only from Chirebandi pond.

The Railway Station pond showed the thick mat of Eichhorniacrassipes, Pistia spp., and Lemna minor while scarce in Devtaki pond during winter and summer season which is the result of high nutrient load in the ponds. The growth and frequency of distribution of different aquatic macrophytes was correlated with an increase in phosphate and nitrogen content of water bodies by Kiranet. al. (2006). It is probably that these nutrients stimulate the rapid organic production by aquatic macrophytes.(Sarkar et.al. 2002).

In the present study, Chirebandi pond showed the maximum diversity in macrophytes while Devtaki and Railway Station pond harbor rich pollution indicator species along with higher density of phytoplankton. This was also observed by Narayana and Somashekhar (2002), Devi et.al.(2007)

\section{REFERENCES}

APHA, (1975): Standard methods for the examination of water and waste water, 14th Ed. APHA AWWA WPCF, Washington-DC.2003

Devi, Ch. G. and Sharma, B.M(2007):Studies on the diversity of the macrophytes in Awangsoipat Lake(Bishnupur), Manipur, India. In:(EdsA.K.Kandya and Asha Gupta) Biodiversity conservation and Legal aspects. AviskarPublishers,Distributors, Jaipur:62-71.

Edmondson, W.T. (1959) : Freshwater Ecology, 2nd Ed. John Wiley \& Sons, Inc. New York.

Fassett, N.C. (1930) : The plants of some Northeastern Wisconsin Lakes. Trans. Wis. Acad. Sci., Arts, Let., 25 : 157 $168 \mathrm{pp}$

Ghavzan, N.J.,Gunale V.R.,Mahajan D.M. and Shirke D.R.(2006) :Effects of environmental factors on ecology and distribution of aquatic macrophytes. Asian Journal of Plant Sciences 5(5):871-880.

Kiran, B.R., Patel, A.N. Vijaya Kumar and Puttaiah, E.T.(2006): Aquatic 
macrophytes in fish culture ponds at Bhadra fish farm, Karnataka. J.Aqua. Biol.21(2): 27-30.

Kumar, R. and Pandit, A.K.(2005): Community architecture of macrophytes in Hokarsarwetland, Kashmir, Ind. J. Environ. And Ecoplan.(10):565-573.

Meshram, C.B. (1996) :Limnological studies of Wadali lake, Amaravati, Ph.D. Thesis.Narayana , J. and Somshekhar R.K.(2002) : Macrophytes diversity in relation to water quality investigation on river Kavery. Ecology and comnservation of lakes, Reservoirs and
Rivers.Arvind Kumar,-I ABD Publishers, Jaipur:87-113

Pennack, R.W.(1978) : Freshwater invertebrates of United States. 2nd ed. John Wiley and Sons Inc., Francisco., 108 pp.

Sarkar, S. (2008) : Norms and the Conservation of Biodiversity, Resonance, Indian Academy of Sciences. 13 (7) : 627-637 pp.

Tonapi, G.T. (1980) : Fresh Water Animals of India, an ecological approach, Oxford and IBH publishing Co. New Delhi.

Table no. 1 :Macrophytes Diversity in Lentic ecosystem during 2005-2007.

\begin{tabular}{|c|c|c|c|c|c|}
\hline S.N. & Macrophytes & Family & C.P & D.P. & $\mathbf{R} . \mathbf{P}$ \\
\hline $\mathbf{A}$ & Free Floating & & & & \\
\hline 1 & Eichhornia Spp. & & - & + & + \\
\hline 2 & Pistia Spp. & Araceae & - & + & + \\
\hline 3 & Lemna minor & Lemnaceae & - & + & + \\
\hline 4 & Wolffia Spp. & Lemnaceae & - & + & + \\
\hline 5 & Salvinia Spp. & Salviniaceae & - & + & + \\
\hline 6 & Azolla Spp. & Salviniaceae & + & - & - \\
\hline B & Submerged & & & & \\
\hline 7 & Hydrilla Spp. & Hydrocharitaceae & + & - & - \\
\hline 8 & Ceratophyllum Spp. & Hydrocharitaceae & + & - & - \\
\hline 9 & Vallisnaria Spp. & Hydrocharitaceae & + & - & - \\
\hline 10 & Potomogeton Spp. & Najadaceae & + & + & + \\
\hline 11 & Najas minor & Najadaceae & + & - & - \\
\hline 12 & Chara vulgaris & & + & - & - \\
\hline $\mathbf{C}$ & Marginal & & & & \\
\hline 13 & Marsileaquadrifolia & Marsileaceae & - & + & + \\
\hline 14 & Marsileaminuta & Marsileaceae & - & + & + \\
\hline 15 & Ipomoea aquatica & Convolvulaceae & + & + & + \\
\hline 16 & Typha Spp. & Typhaceae & + & + & + \\
\hline 17 & Cyperus Spp. & Cyperaceae & - & + & + \\
\hline 20 & Jussiaea Spp. & Onagraceae & + & - & - \\
\hline 21 & Ludwigia Spp. & Onagraceae & + & - & - \\
\hline
\end{tabular}




\begin{tabular}{|c|l|l|c|c|c|}
\hline 22 & Lathrum Spp. & Lythraceae & + & - & - \\
\hline D & Emergent & & & & \\
\hline 23 & Nymphoides Spp. & Nymphaeaceae & + & - & - \\
\hline 24 & Nelumbo Spp. & Nymphaeaceae & + & - & - \\
\hline 25 & Nymphaeastellata & Nymphaeaceae & + & - & - \\
\hline 26 & Nymphaeanauchali & Nymphaeaceae & + & - & - \\
\hline
\end{tabular}

(C.P.-Chirebandi Pond, D.P.- Devtaki Pond, R.P.- Railway Station Pond) Macrophytes of Lentic Ecosystems Under Study

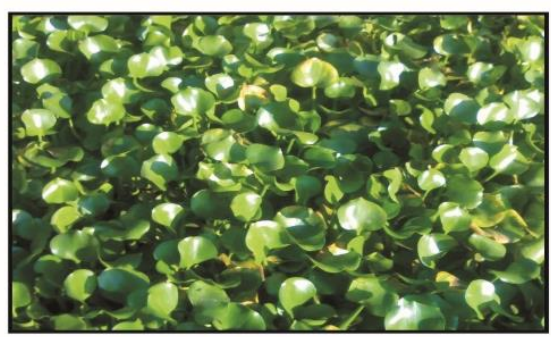

Eichhornia Spp.

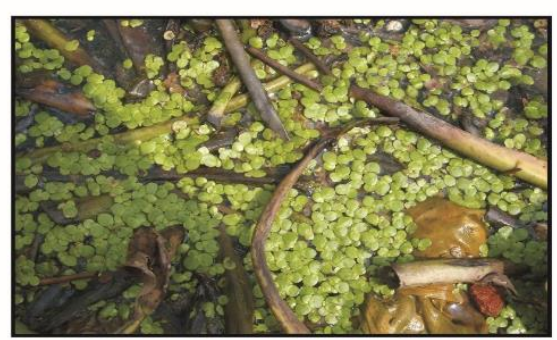

Lemna minor

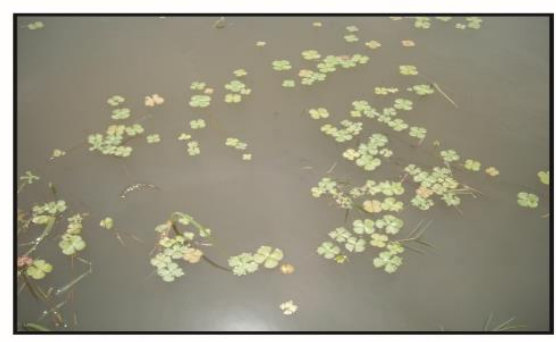

Marselia Spp.

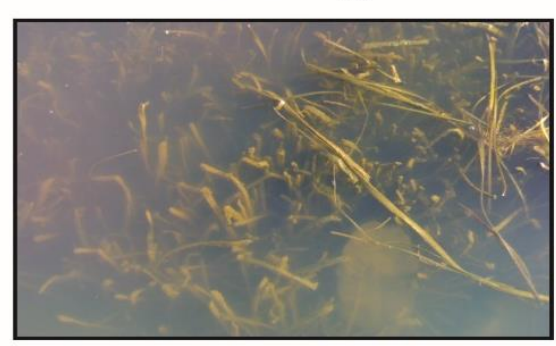

Vallisneria Spp.

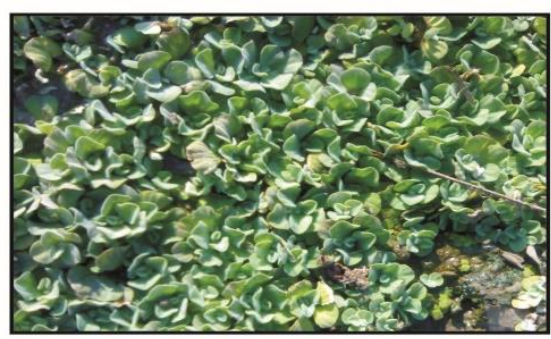

Pistia Spp.

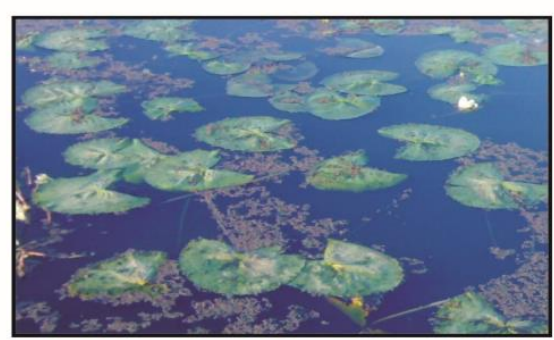

Nelumbo Spp.

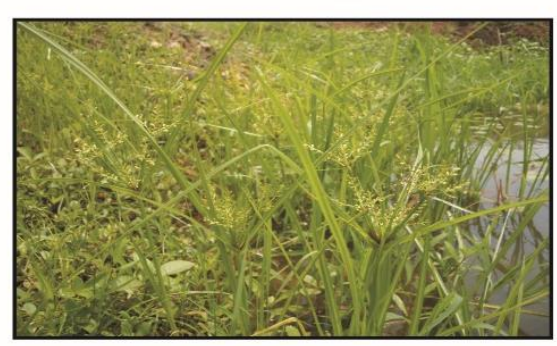

Cyperus Spp.

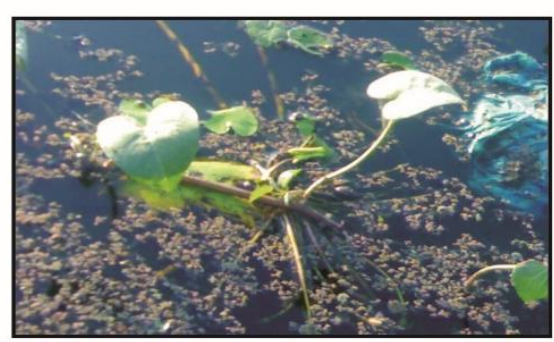

Ipomoea aquatica 